Soviet academics

\section{No room at the top?}

THE Soviet Union, with more than a million people of working age with higher education, is having difficulty finding jobs for them all. The rapid expansion of higher education during the past three decades to meet the challenge of the "scientific and technological revolution" has proved, it appears, too successful. Some universities and institutes seem now to be attempting to obstruct researchers hoping to submit a dissertation for a higher degree on the grounds that no posts are available for them.

The problem is exacerbated by the Soviet two-tier system of higher degrees and by the rigid separation of available posts into those for "junior" and "senior" scientific researchers. It is still fairly easy for a Candidate of Sciences (roughly equivalent to a PhD) to get a position as a "junior scientific worker"'. The trouble comes when he or she wants to proceed to the degree of Doctor of Science. If there are no senior posts available at an institute or university, the argument goes, why should a junior scientific worker or assistant lecturer want to take a doctorate? A doctor cannot be employed in a junior post, so anyone who insists on submitting a doctoral dissertation must do it elsewhere.

During the past few years, the issue of higher degrees and the jobs appropriate to them has been taken up on a number of occasions by the weekly Literaturnaya Gazeta, which published in 1976 a proposal that the difficulty could be avoided by questioned the relevance of the candidate degree (introduced as a temporary expedropping the word "junior". In 1982, it

dient in the 1930 s to satisfy an urgent need for trained personnel). Last week, it launched yet another "debate" on the subject, with a letter by Academician V. L. Ginzburg, of the Landau Institute of Theoretical Physics, entitled "Is it necessary to block those presenting dissertations?" - a question which he answers with a firm negative.

The publication of scientific articles and the defence of dissertations are, in Ginzburg's opinion, the "basic and often unique form" in which a scientist can demonstrate his or her results. Placing impediments in the way of these activities, he says, imposes on victims a "moral trauma" and takes away their legal rights. Jobs, however, are a quite different matter, and if a new doctor of science wants to stay on in his old (junior) job, that is his business. (In Soviet conditions, in which the preparation of a doctoral dissertation can take up 10 to 15 years of working life, it is hardly surprising that Ginzburg regards it as a scientist's "basic" activity.)

Ginzburg argues that the defence of a dissertation for a higher degree should be free of administrative restraints - though subject, of course, to those imposed by the Higher Attestation Committee (which, incidentally, cover character and political rectitude as well as purely academic considerations). He does not mention, however, the main practical objection to Doctors of Science in "junior" posts - the Soviet academic salary structure which calculates salaries not on the basis of the post held but on the qualifications of the incumbent.

Vera Rich

\section{Insurance wanted on Greenland explorers}

EXPEDITIONS planning to visit Greenland are likely to find it more difficult to raise adequate support from this year. The Commission for Scientific Research in Greenland is insisting on much larger guarantees against the cost of rescue operations - twice as much by some accounts and visitors will in future have to liaise more closely with the authorities and stick to an agreed route. The number of private scientific expeditions may fall as a result.

The commission, based in Copenhagen, says the tight new conditions have been imposed because of several fatal accidents last year. Although all the fatalities occurred on sporting rather than scientific expeditions, the commission is taking no chances. All agree that the cost of rescue operations in Greenland is enormous: helicopters, usually the only means of rapid transport, start at $\$ 1,500$ per hour. The commission and the Ministry for Greenland in Copenhagen have been frustrated at the number of expeditions setting off into remote Greenland with what is seen as wholly inadequate equipment and with little or no experience of Arctic travel.

There may also be a political element to the decision. Although still formally a part of Denmark, Greenland now has effective home rule, and - as is shown by its recent decision to leave the European Economic Community - is willing to go its own way when the occasion arises. As Denmark already subsidizes the country to a large extent, attitudes may be hardening.

The commission is adamant that bona fide scientific expeditions will still be welcome in Greenland. Its aim seems to be to eliminate many of the badly organized sporting expeditions which have been increasing in recent years. Well-planned expeditions, it says, will not be imperilled.

Others are less sure. There were 90 scientific expeditions to Greenland last year, of which 64 were not Danish. The cost of insurance - proof of which must be shown to the commission - may be a significant part of the cost of an expedition, particularly to a remote area.
US research freedom Suit against farm machines

Los Angeles

THE freedom of a university to choose its own research objectives went on trial in California last week.

In an unprecedented court case, a group of farm workers challenged the right of the University of California to use public research funds to develop labour-saving machines that, according to the farm workers, primarily benefit owners of large farms.

The 19 workers say mechanized devices developed by the university's agricultural extension division have eliminated thousands of farm jobs, promoted the growth of large land holdings and prevented workers from starting small farms of their own.

The university denies the charges and says that no more than $3-4$ per cent of all its agricultural research has ever gone to developing the labour-saving machines. It also says that much of its research has directly benefited both small farmers and farm workers.

The case is being tried in Alameda county, across the bay from San Francisco and just south of the Berkeley campus. Plaintiffs are represented by California Rural Legal Assistance, a federallysubsidized public interest law firm.

The workers are seeking a court order that would limit the influence of private industry in helping to set research priorities for university scientists and to require that researchers prepare "social consequence statements" before taking on projects.

The consequences of stopping research because what might be learned could some day be harmful "is staggering", said university lawyer Gary Morrison. "Professors should be allowed to inquire into areas of academic merit, where they believe that new knowledge should be uncovered, without judicial interference and without having to consider some perceived downstream, social or economic impact that might occur."

The judge in the case agreed that it is difficult to determine in advance what the economic and social impacts of new knowledge will be. But he said he would allow the plaintiffs to determine if the university's procedures and policies favour private over public interests.

University lawyers have likened the farmworkers' challenge to last century's Luddite revolt to stop the use of laboursaving machines. But Ralph Abascal, representing the California workers, said the comparison is unfair and "that Congress intended the system of publicsupported agricultural research to help the little person, the person most in need, not mechanization research for large industries"'
Sandra Blakeslee 